\title{
A VERSENYKÉPESSÉG ÉS A TÁRSADALMI INNOVÁCIÓK KAPCSOLATA
}

\author{
Lipták Katalin \\ egyetemi docens, Miskolci Egyetem, Világ-és Regionális Gazdaságtan Intézet \\ 3515 Miskolc, Miskolc-Egyetemváros, e-mail: regkata@uni-miskolc.hu
}

\begin{abstract}
Absztrakt
A tanulmány célja, hogy a korábbi munkáimban feltárt társadalmi innovációk közül olyanokat vizsgáljak meg és ismertessek, amelyek az Észak-magyarországi régióban sikeresnek mondhatók, az innováció által a térség vagy az adott település versenyképességi pozíciói javultak. Az Észak-magyarországi régióban két olyan innovációra esett a választásom, amelyeket kevésbé ismerünk: az Önálló Másság Életminőség Fejlesztö Alapitvány tevékenységét és társadalmi innovációját, valamit a boldvai tökmagolaj elöállitását ismeretem. A több évtizede müködö társadalmi innovációk más térségekbe való átültetése sokszor nehézségekbe ütközik, pedig egy-egy sikeres innováció átvétele javithatná az adott térség versenyképességét.
\end{abstract}

Kulcsszavak: versenyképesség, társadalmi innováció, Észak-Magyarország.

\begin{abstract}
The aim of the study is to examine and describe the social innovations explored in my previous work that can be said to be successful in the Northern Hungarian region, the competitiveness positions of the region or the given settlement have improved as a result of the innovation. In the region of Northern Hungary, I chose two innovations that we are less familiar with: the activity and social innovation of the Independent Otherness Quality of Life Development Foundation, (Önálló Másság Életminöség Fejlesztö Alapitvány) and the production of pumpkin seed oil in Boldva. The transfer of social innovations that have been in place for decades to other regions is often difficult, although the adoption of a successful innovation could improve the competitiveness of a given region.
\end{abstract}

Keywords: competitiveness, social innovation, Northern Hungary.

\section{Bevezetés - Versenyképességet befolyásoló tényezők}

A versenyképesség egy olyan összetett közgazdasági fogalom, amely definiálásával kapcsolatban több eltérő nézőpont fogalmazódott meg az évek során [1]. Az egyik álláspont képviselői, Porter és Krugman szerint, a versenyképesség nem makroökonómiai kategória. Véleményük szerint, a makrogazdasági szinten történő értelmezés abból a félreértésből származik, hogy a legtöbb közgazdász, a versenyképesség egyetlen nemzetgazdasági szinten értelmezhető tényezőjét, a termelékenységet, tévesen versenyképességnek nevezi. A másik felfogás szerint a makrogazdaságok nemezközi versenyképessége igen is értelmezhető, de vizsgálata máshogy történik, mint mikrogazdasági szinten, ugyanis a nemzetgazdaságok nem ugyanúgy ,versenyeznek” egymással, mint a vállalkozások. Török Ádám szerint, viszont a versenyképesség mikro- és makrogazdasági szinten is értelmezhető. Mikroszinten a vállalatok piaci teljesítményének mutatójaként tünik fel, makro-szinten pedig a nemzetgazdaságok általános állapotának jellemzésére szolgál [2]. Komplexitását tovább fokozza a 
nemzetközi verseny átalakulása, a globalizáció felerősödése és a nemzetgazdaságok nyitottságának folyamatos növekedése [1].

Ha elfogadjuk azt a megállapítást, miszerint létezik nemzetgazdasági szintü versenyképesség, akkor ex post és ex ante megközelítésből mérhetjük azt. Az ex ante a globális versenyben való sikeres helytállás feltételét az üzleti környezet vizsgálja, és azt, hogy ez milyen hatással van az adott nemzetgazdaság jövőbeli versenyképességére. Az ex post szemléletmód pedig a múltbeli gazdasási teljesítményre és annak versenyképességre gyakorolt hatására fókuszál. Az ex post versenyképesség legfontosabb mérőszáma a GDP (a jövedelem) és annak növekedési üteme, valamint az egy före jutó GDP (fajlagos jövedelem), melyet a munkatermelékenység és a foglalkoztatási ráta határoz meg. Azonban a GDP és a GDP/fő a gazdasági fejlődés mutatószáma is, tehát az országok esetében a versenyképesség nem más, mint a gazdasági növekedés egyfajta újra fogalmazása. Ennek értelmében az az ország tekinthető versenyképesnek, ahol magas a foglalkoztatottság és a termelékenység [1]. A versenyképesség tehát a gazdasági növekedés feltétele.

A versenyképesség nemzetközi elemzésénél a vizsgálatba bevont országok számát illetően, megkülönböztetünk célország központú és célország nélküli összehasonlításokat. Az előbbi az összehasonlítás alapjául vett ország versenyképességét méri össze a többi ország versenyképességével, az utóbbi nem választ ki célországot, hanem több ország versenyképességét hasonlítja össze [3]. Célország központú összehasonlítást a Gazdaságkutató Intézet végez, amely Magyarország versenyképességét hasonlítja össze a környezö országokéval. Eredményeit a versenyképességi évkönyvekben közli 2006-tól kezdve. Ezen évkönyvek értelmében a versenyképességet befolyásoló legföbb tényezők: a külföldi müködötőke befektetések, az infrastruktúra, a kutatás-fejlesztés és innováció, az üzleti környezet (munkaerőpiaci szabályozás), a humán erőforrások (munkaerőpiac, demográfia), a költség-tényezők (bérek, árfolyamok), és a termelékenység (munkatermelékenység).

A Világgazdasági Fórum (World Economic Forum - WEF) minden évben közzé teszi a Globális Versenyképességi Indexet a GCI (Global Competitiveness Index) mutatót. Az IMD (Institute for Management Development) pedig minden évben bemutatja versenyképességi rangsorát (World Competitiveness Scoreboard).

A WEF három pillérre bontja a versenyképességet befolyásoló tizenkét tényezőket:

1. pillér - alapkövetelmények alindex: intézmények, infrastruktúra, egészségügy, makroökonómia, alapfokú oktatás

2. pillér - hatékonyságfokozók alindex: felsőoktatás, termékpiac, munkaerőpiac, pénzpiac, technológia, piacméret

3. pillér - innováció és kifinomultság alindex: üzleti kifinomultság, innováció [4].

Az IMD négy csoportra osztja a tényezőket:

1. gazdasági teljesítmény: belföldi gazdaság, nemzetközi kereskedelem, külföldi beruházások, foglalkoztatás, árak

2. kormányzat hatékonysága: állami pénzügyek, adópolitika, intézményi keretek, törvények, szociális keretek

3. üzleti szféra hatékonysága: termelékenység, munkaerőpiac, pénzügyek, irányítási politika, üzleti magatartás

4. infrastruktúra: általános, technológiai, tudományos, egészségügy, oktatás.

\section{Európai Regionális Versenyképességi Index elemzése}

A nemzetgazdasági szintủ versenyképességet követően megvizsgáltam a regionális versenyképességet (RCI), amelyet az Európai Unióban évek óta mérnek regionális szinten és 3 alindex 11 témaköre mentén 
kerül meghatározásra a konkrét érték. Az alap dimenzióba tartozik az intézményi környezet, a makrogazdasági hatékonyság, az infrastruktúra, az egészségügy és a közoktatás. A hatékonyság dimenziójába a felsőoktatás és az élethosszig tartó tanulás, a munkaerőpiaci hatékonyság és a piaci méret tartozik. Az innováció dimenziójába a technológiai hatékonyság, az üzleti szerkezet és az innovációk tartoznak. A legfrissebb 2016.évi adatok alapján többközpontú mintázat figyelhető meg, melyben a jól teljesítő fővárosi és városi területek a versenyképesség fö motorjai. E fejlett területekről kiinduló tovagyürüző hatás figyelhető meg Északnyugat-Európa nagy részén. Néhány ország esetében a fővárosi térség húzóereje figyelhető meg, így hazánkban is. A regionális versenyképességi index a $263 \mathrm{db}$ NUTS 2 szintủ régió közül 2016-ban Közép-Magyarország a 152., Közép-Dunántúl a 205., Nyugat-Dunántúl a 207., Dél-Alföld a 224., Dél-Dunántúl a 227., Észak-Magyarország a 231., Észak-Alföld pedig a 232. helyre került. Az alindexek és az index rangsor értékei az alábbi táblázatban láthatóak. A magyarországi régiók közül a legrosszabb helyezéssel az Észak-magyarországi régió rendelkezett.

1. táblázat. RCI alindex és RCI index rangsor értékek (2016)

\begin{tabular}{|l|c|c|c|c|}
\hline régió & $\begin{array}{c}\text { alap } \\
\text { alindex }\end{array}$ & $\begin{array}{c}\text { hatékonyság } \\
\text { alindex }\end{array}$ & $\begin{array}{c}\text { innovációs } \\
\text { alindex }\end{array}$ & RCI \\
\hline Közép-Magyarország & 223 & 145 & 110 & 152 \\
\hline Közép-Dunántúl & 226 & 184 & 207 & 205 \\
\hline Nyugat-Dunántúl & 224 & 190 & 206 & 207 \\
\hline Dél-Dunántúl & 234 & 215 & 218 & 227 \\
\hline Észak-Magyarország & $\mathbf{2 3 6}$ & $\mathbf{2 2 3}$ & $\mathbf{2 2 5}$ & $\mathbf{2 3 1}$ \\
\hline Észak-Alföld & 233 & 224 & 237 & 232 \\
\hline Dél-Alföld & 235 & 202 & 223 & 224 \\
\hline
\end{tabular}

Forrás: Európai Bizottság RCI értékek

\section{Társadalmi innovációk Észak-Magyarországon}

A társadalmi innováció definiálása a szakirodalomban még nem egységes [5], [6], [7], [8], [9], [10]. ugyanakkor minden, a fennálló társadalmi problémák leküzdését szolgáló újszerü, innovatív ötlet társadalmi innovációnak tekinthető. A társadalmi innováció hozzájárulhat a periférikus vagy vidéki területeken élők életminőségének javításához és segítheti a felzárkózást mind társadalmi, mind gazdasági értelemben. Olyan társadalmi innovációkat gyüjtöttem össze, amelyek vagy elmaradott térségek fejlesztésére vagy hátrányos helyzetű marginális társadalmi csoportok felzárkóztatására születtek az elmúlt években.

Magyarországon számos társadalmi innovációt derítettem fel és elemeztem korábbi munkámban [11], ezek közül a legismertebb az Észak-magyarországi régióban a Szimbiózis Alapítvány munkássága a megváltozott munkaképességüek foglalkoztatása terén vagy a hernádszentandrási innovatív közfoglalkoztatási program. Jelen tanulmányban egy szintén miskolci alapítvány, az Önálló Másság Életminőség Fejlesztő Alapítvány (továbbiakban: ÖMÉFA) munkásságát mutatom be, ami a Szimbiózis Alapítványhoz hasonlóan megváltozott munkaképességüeket foglalkoztat, de kevésbé ismert.

Az ÖMÉFA Miskolcon müködő közhasznú civil szervezet, amelyet 2006-ban alapítottak, az intézmény vezetője Patkó Gabriella. Céljuk egyrészt a szociális nappali intézmény müködtetése, másrészt fejlesztő szolgáltatások nyújtása a fogyatékos személyeknek annak érdekében, hogy alkalmasak legyenek a nyílt munkaerőpiacon történő munkavégzésre. A műhelyeket 2009-től 2017. március 31-ig szociális intézményi foglalkoztatással müködtették, mostanra a jogszabályváltozás miatt helyesen úgy hangzik, hogy fejlesztő foglalkoztatási szolgáltatást nyújtanak. Az intézetvezető 
szakember hiányában az intézmény zavartalan müködtetése érdekében sokféle feladatot lát el. A nappali intézményben 12 fő dolgozik, egy intézményvezető, három terápiás munkatárs, ebből egy szakmai vezető is, és a többi szociális ápoló és gondozó. A szervezet munkaerő-közvetítő szerepet is betölt, Borsod-Abaúj-Zemplén megye egész területén immáron körülbelül 600 cég együttmüködésével, 10 éve látják el ezt a feladatot is. A szolgáltatás keretében közvetítő irodákat müködtetnek Kazincbarcikán, Szerencsen, Miskolcon. Nagyban hozzásegíti a vállalatok megváltozott munkaképességüek foglalkoztatására való ösztönzését a törvényileg meghatározott rehabilitációs hozzájárulás, melyet akkor fizetnek a munkáltatók, ha a foglalkoztatottak száma 25 fó feletti és az általa foglalkoztatott megváltozott munkaképességüek aránya nem éri el az 5\%-ot. Jellemzö, hogy a nagyobb cégek felkeresik őket. Sajnos human erőforrás hiányában, és a kapacitásait maximálisan kihasznált intézményvezető miatt a szervezet népszerüsítésére már nem jut idő és energia. Az ÖMÉFA-ról a Martin János Szakképző Iskolában hallhatnak a szülői értekezleteken, de leginkább a szülők közötti és ismeretségen keresztüli ajánlásokon juthatnak el a potenciális munkavállalók a szervezethez. Igaz van honlapuk, de az interneten sem aktívak. További hátrányként említendő, hogy ki kellene szélesíteni a szakmák körét, amikben foglalkoztatni tudnának például egy asztalost, száraztészta készítőt stb. Az elnök lát el „mindent”, ahogy azt ő megfogalmazta, néhány szülő besegít, kevés ember motivált arra, hogy egy civil szervezetnél dolgozzon. Az intézményvezetőn kívül van még két pénzügyes kolléga, ebböl az egyik munkaügyi végzettségü, megváltozott munkaképességü és 6 órában látja el a feladatokat. Külső hátrány, hogy általában kevés a szakember, szociális szakember, valamint a szervezet nem tud kedvező bért fizetni a szociális szakemberek foglalkoztatására (minimálbért adnak). Kockázati tényező, hogy a foglalkoztatási projektek révén évente változó, nem kiszámítható támogatások állnak rendelkezésre, minden évben pályázni kell. Mivel alapvetően pályázati pénzből müködnek, ezért ez egy hullámzást idéz elő a foglalkoztatásban. Közfeladatot látnak el, rendelkezésre áll az állami normatíva, de ez csak az intézet fenntartására használható fel, sajnálatos, hogy ez 2006-tól változatlan, 500 ezer Ft/fö/év összegben van meghatározva a civil szervezetek részére, ebből gazdálkodják ki a dolgozók béreit és a közüzemi díjakat.

Az ÖMÉFA a szociális nappali intézményen belül 5 mühelyt müködtet. A varró mühelyben bábokat, asztalterítőket, a szövő mühelyben textil alapú tárgyakat, a papír mühelyben papír masniból készült képkereteket, képeslapokat készítenek, a kerámia mühelyekben különböző technikával elöállított kerámiából készült dísztárgyakat és háztartási eszközöket. A mühelyben készült tárgyak egyedi termékek, azokat eladásra készítik, vásárokra, falunapokra vagy más hasonló rendezvényen megjelenve, ill. a szülők is vásárolhatják, továbbá megrendelésre is dolgoznak. A bevételeket visszaforgatják a foglalkoztatásra, alapanyagot vásárolnak belőle, további termékek készülnek belőle. Nappali intézményükben 80 fö felvételére van engedélyük. A munkavállalóik Borsod-Abaúj-Zemplén megyéből járnak be, fóképp a miskolci, tiszaújvárosi, kazincbarcikai és edelényi járásokból, a foglalkoztatotti létszám két éve stabil: 70 fö.

A fejlesztő foglalkoztatási szolgáltatás keretében az intézményben 16 fogyatékkal élő fiatal dolgozik 4-6 órában. Amennyiben munkaszerződésben vannak a foglalkoztatottal, munkabért, amennyiben fejlesztési jogviszonnyal állapodtak meg, órabért/munkabér támogatást kapnak. A szervezet akkreditált intézmény is, ami lehetővé teszi a megváltozott munkaképességüek foglalkoztatását, 22 fö ilyen munkavállaló van most jelen a szervezetnél.

A tevékenységük kimenetelének visszacsatolásáról (hatásáról) megkérdezve a vezetőt, kérdésünkre elsőként kérdéssel válaszolt: „Mivel lehet ezt a hatást mérni? Igazából azzal tudjuk mérni, hogy milyen hosszú távon van foglalkoztatva az ilyen személy."

A munkaerö-közvetítő szolgáltatásukkal éves szinten 60-80 fö́t tudnak elhelyezni. Kérdeztük a programok sikerességét, az ellenőrzési és visszacsatolás lehetőségeit. 6 hónapos utókövetést alkalmaznak a munkaerő-piaci szolgáltatásban. Ha például valakit elhelyeznek egy vállalatnál, ők 
felhívják a dolgozót és érdeklődnek felőle, a vezető a visszajelzések alapján elmondta, hogy a vállalatokhoz kiközvetített munkavállalóikkal meg vannak elégedve. Sőt, kiemelte, hogy lojálisabbak, kevesebbet mennek táppénzre, alacsonyabb a körükben a fluktuáció szemben az egészséges kollégákkal. Pozitívum, hogy a HR-essel együttmüködnek, annak érdekében, hogy az egyes üres pozíciókra a megfelelő személyt tudják elhelyezni.

A másik példa egy Borsod-Abaúj-Zemplén megyei település, Boldva példája, ahol közfoglalkoztatottak bevonásával hidegen sajtolt tökmagolajat állítanak elö és értékesítenek. Manapság a helyi termékek egyre keresettebbek országszerte, ugyanis kezd visszatérni a globalizáció ellentrendje, próbálunk tudatosabban vásárolni, keressük azokat a termékeket, élelmiszereket, amelyek hazánkban vagy esetleg a régiónkban készültek, onnan származnak. Ezeknek a termékeknek a vásárlása nem csak a fogyasztó tudatosságát tükrözi, hanem a hazai gazdaság fellendüléséhez is vezethet. Ha még szükebb keresztmetszetben vizsgájuk ezt, sok kistérség, település egyik esélye a gazdaságba való bekapcsolódásra a helyi termék. Ezzel egy időben a terület fejlődésében is szerepet játszanak a helyi termékek, ugyanis ahhoz hogy valamit elöállítsanak meg kell termelni a nyersanyagot, el kell készíteni a terméket és értékesíteni azt, ez mind foglalkoztatással is jár [12].

A tökmagolaj a boldvai olajüzemben az elsődleges termék, ennek elöállítására hozták létre. A közfoglalkoztatás államilag támogatott foglalkoztatási forma, célja a minél nagyobb számú foglalkoztatás, ezzel a munkanélküliség csökkentése. Boldván ez a Start Közmunkaprogram keretein belül többek között a földmüveléssel, gyógynövény, olajtök és egyéb mezőgazdasági termékek termesztésével történik. Ebböl következik az is, hogy itt olyan logika szerint alakították ki az üzemet, hogy az olajtök termesztésével, betakarításával, a magok préselésével, az olaj csomagolásával minél több embernek adjanak munkát. Az olajtököt saját földterületen termesztik, félig gépesített eljárással, nagyban hozzájárulnak a helyi erőforrások kisléptékű hasznosításához, illetve az „,alapanyag beszerzés” során is a szállítási költségek kiesnek, minimalizálódnak. A melléktermékek hasznosítása és értékesítése miatt a hulladéktermelődés is alacsonyabb. A gondozott üzemi környezet megjelenik, egy korábban kihasználatlan, elhagyatott épületet újítottak fel az üzem számára. A boldvai önkormányzat által müködtetett üzem a helyi vállalkozókat emelte ki, mint leendő partnerek. A tökmagolaj sajtolása pár éve müködik, így még a kezdeti szakaszban van. Eredményként megjelenik a foglalkoztatás, mint pozitív gazdasági hatás, viszont a kis létszám miatt nem annyira jelentősen. Boldván az értékesítésből származó bevételek az önkormányzathoz kerülnek, amit az üzembe forgatnak vissza, hosszútávon az önfenntartás lenne a cél.

\section{4. Összegzés}

Megállapítható, hogy a társadalmi innovációs potenciál és a versenyképesség szoros kapcsolatban van egymással. A társadalmi innováció megvalósulásának feltétele, hogy erős helyi kapcsolati háttér és a közvetlen környezeten túlnyúló kapcsolatokkal is kialakított innovátor álljon az ötletek megvalósítása mögött. Ha elfogadása viszonylag hamar megtörténik, az innováció elterjedése gyors, hatása maradandó. A fenntartható, jó kapcsolat alapjait képezi, hogy az innovátor rendelkezzen bizonyos szükséges innovációs készségekkel. Ez magában foglalja az újra való nyitottságot, a kreativitást, a kezdeményezőkészséget. Ezek a tulajdonságok nem mindig párosulnak egyetlen személyben, így az innovátor akár egy csoport is lehet. Ha egy térségben több különböző társadalmi innováció jött létre, akkor a fejlesztések révén a térség versenyképességi tényezői is javulni fognak. 


\section{Köszönetnyilvánítás}

A cikkben/előadásban/tanulmányban ismertetett kutató munka az EFOP-3.6.1-16-2016-00011 jelü „Fiatalodó és Megújuló Egyetem - Innovatív Tudásváros - a Miskolci Egyetem intelligens szakosodást szolgáló intézményi fejlesztése” projekt részeként - a Széchenyi 2020 keretében - az Európai Unió támogatásával, az Európai Szociális Alap társfinanszírozásával valósul meg.

\section{Irodalom}

[1] Lengyel, I.: A regionális versenyképességről, Közgazdasági Szemle, 47(12), (2000) pp. 969-979.

[2] Török, Á.: Mit mivel mérünk? A versenyképesség értelmezéséröl és mérési problémáiról. In: Európai Tükör Mühelytanulmányok. EU-csatlakozás és versenyképesség. A Miniszterelnöki Hivatal Kormányzati Stratégiai Elemző Központjának 93. kiadványa, Budapest, 2003.

[3] Szilágyi, Gy.: A versenyképesség mérése a nemzetközi összehasonlitások módszertanának tükrében, Statisztikai Szemle, 86(1), (2008) pp. 6-19.

[4] Lukovics, M.: Térségek versenyképességének mérése, JATEPress, Szeged, 2008.

[5] Benedek, J., Kocziszky, Gy., Veresné Somosi, M.: Új innovációs paradigma? Regionális társadalmi innovációs potenciál javitásának lehetösége szakértői rendszer segitségével, lehetőségek és korlátok, In: Veresné Somosi Mariann: „Mérleg és Kihívások” 2015 IX. Nemzetközi Tudományos Konferencia, Konferencia kiadvány

[6] Benedek, J., Kocziszky, Gy., Veresné Somosi, M., Balaton, K.: Generating and measuring regional social innovation, Theory Methodology Practice: Club of Economics in Miskolc 12 (special issue), (2016) pp. 14-25. https://doi.org/10.18096/TMP.2016.02.02

[7] G. Fekete, É.: Társadalmi innovációk a felzárkóztatás szolgálatában: Dél-Cserehát - Nyitás a jövőre, Miskolci Egyetem, Gazdaságtudományi Kar, Miskolc, 2015.

[8] Kocziszky, Gy., Benedek, J., Veresné Somosi, M., Balaton, K.: Regionális társadalmi innováció generálása szakértői rendszer segitségével, Észak-magyarországi Stratégiai Füzetek, 12(2), (2015) pp. 4-22.

[9] Kocziszky, Gy., Veresné Somosi, M., Balaton, K.: A társadalmi innováció vizsgálatának tapasztalatai és fejlesztési lehetősége, Vezetéstudomány, 48(6-7), (2017) pp. 15-19. https://doi.org/10.14267/VEZTUD.2017.06.02

[10] Varga, K.: A regionális társadalmi innováció kérdései, International Journal of Engineering and Management Sciences, 2(4), (2017) pp. 602-616. https://doi.org/10.21791/IJEMS.2017.4.49.

[11] Lipták, K., Horváth, K.: Társadalmi innovációk szerepe a foglalkoztatáspolitikában és a vidékfejlesztésben, Észak-magyarországi Stratégiai Füzetek 15(3), (2018) pp. 55-68.

[12] Burka, N., G. Fekete, É.: A hidegen sajtolt tökmagolaj, mint helyi termék szerepe a helyi fejlödési folyamatokban. In: Lipták Katalin (szerk): Társadalmi innováció és felelősségvállalás ÉszakMagyarországon, Miskolc, 2017. https://doi.org/10.17836/EC.2017.2.032 